\title{
A Corpus-Based Evaluation on Two Different English for Nursing Purposes (ENP) Course Books
}

\author{
Alif Fairus Nor Mohamad (Corresponding author) \\ Universiti Putra Malaysia, Malaysia \\ E-mail: aliffairus@upm.edu.my \\ Sharifah Nor Puteh \\ Universiti Kebangsaan Malaysia, Malaysia
}

\author{
Doi:10.7575/aiac.alls.v.8n.2p.196 \\ URL: http://dx.doi.org/10.7575/aiac.alls.v.8n.2p.196
}

Received: 14/03/2017

Accepted: 20/04/2017

\begin{abstract}
It is difficult for most of the second language learners in Malaysia to function proficiently in English language due to limited vocabulary knowledge. It has also been challenging for TESL graduates to fit in as ENP teachers due to the lack of specialized vocabulary knowledge in nursing field. Thus, a course books has always been a highly dependable aid in facilitating the teaching and learning in an ENP classroom. The objective of this research is to identify the possible pedagogical aspects of two ENP commercial course books (Oxford English for Careers Nursing 1" (OEFCN1) written by Tony Grice and "Nursing Your English Second Edition" (NYE) by Siti Salina Salim and Mazura Mastura Muhammad) in socializing learners into their discourse communities. The present research looks at the extent of vocabulary coverage in comparison with General Service List (GSL), Academic Word List (AWL), Nursing Education Word List (NEWL) and the 2,000 most frequent nursing words. These course books were photocopied, scanned and converted into computer text files before they were analyzed using WordSmith 4.0 as it is able to provide elemental knowledge on the vocabulary coverage in both course books. The results indicated that both books showed significant result in terms of their coverage based on the three word lists. On the other hand, it is proven that the 2000 most frequent nursing words wordlist is not able to cover as much tokens as compared to GSL, AWL and NEWL combined.
\end{abstract}

Keywords: English for Nursing Purposes (ENP), Corpus Based Study, ENP Vocabulary

\section{Introduction}

English for Nursing Purposes (ENP) is one of the sub-branches of English for Specific Purposes (ESP). Its target audiences are those non-English speaking student nurses who need career-specific language: language that is useful for their work-related duties. It depicts skills and competency level beyond that of general English. ENP or ESP is not testable on the Test of English as a Foreign Language (TOEFL), the Test of English as a Foreign Language (IELTS) or even other general English language tests. It requires its own course materials, examinations and benchmarks which must be designed and written by professionals in that specific career field.

Unfortunately, the English instructors or teachers who are responsible in teaching the students may also encounter difficulties; not knowing the vocabulary to be focused on as they are not from the nursing background. Having a good awareness of academic words has been emphasized for achievement at tertiary levels of education (Ward, 2009; Nation, 2001; Coxhead, 2000; Nation \& Waring, 1997). Thus, the best solution to overcome this matter would be by looking at a corpus of the field in order to 'undergo and understand' the way the vocabulary is presented in the nursing text. On the other hand, the field of nursing is exclusive in the sense that they have a specialized set of vocabulary which is distinct from other fields.

Therefore, recognising the coverage of diverse vocabularies obtainable in a course book would permit the educator to facilitate better teaching and learning in discovering the finest method for introducing the language items whether they are old or new. By doing this, high frequency words will be more significant not only for teaching, but also for learning. Nation (1990; 2001) asserts that an ESL/EFL student can maximise his/her understanding of an academic text if he/she can understand $95 \%$ of the vocabulary in the text. This can be achieved by mastering the first 2000 words of the General Service List (GSL) introduced by West (1953) and the Academic Word List (AWL) introduced by Coxhead (2000). Mukundan and Ng (2012) state that Nursing Education Word List (NEWL) is able to provide comprehension for the remaining technical words in a nursing academic text.

On the other hand, Nor Mohamad and $\mathrm{Ng}$ (2013) point out that wordlist of the 2,000 most frequent nursing words is able to help students to read betters if the students use it as it is a list created combining GSL, AWL and technical words in nursing academic texts. 
Thus, the present study intends to explore the effectiveness of two different English for Nursing Purposes (ENP) course books in terms of the vocabulary coverage based on the wordlists stated earlier. The objectives of this study are:

1) To determine the coverage of vocabulary used in both ENP course books in comparison with the General Service List (GSL)

2) To determine the coverage of vocabulary used in both ENP course books in comparison with the Academic Word List (AWL)

3) To determine the coverage of vocabulary used in both ENP course books in comparison with the Nursing Education Word List (NEWL)

4) To determine the coverage of vocabulary used in both ENP course books in comparison with the 2,000 most frequent nursing words

\section{Literature Review}

As per Hutchinson and Waters (1987), ESP is a way to deal with language teaching in which all choices as to substance and technique depend on the learners' explanation behind learning. Since 1960's, as expressed by Dudley-Evans and St. John (1998), ESP has turned into an imperative and creative action inside the Teaching of English as a Foreign and Second Language development. First and foremost, English for Science and Innovation was the most wanted region of ESP with a specific consideration being paid to particular assortments specialized English. Besides, Lattore (1969), Swales (1971) and Selinker and Trimble (1976) created sub-branches of ESP as English for Academic Reason (EAP) and English for Occupational Purposes (EOP) in their tree of ELT (English Language Teaching).

English for nursing is among the new sub-branches to the field of English for specific purposes (ESP). The investigation of different needs have added to a more total comprehension of the discourse community of nursing and the advancement of a scientific classification of vocabulary used in nursing. Nursing assignments such written work reports, and conveying at work environment utilizes English language majorly. This puts the importance on the need of English as a second language (ESL).

\subsection{Corpus Based Study}

There are numerous approaches to characterize a corpus; however accord is making progress that a corpus is a gathering of (1) machine-readable (2) authentic text which is (3) sample to be (4) illustrative of a specific language or language assortment (McEnery et al., 2006). Also, a corpus is a gathering of writings, written or spoken which is put away on a computer (O'Keeffe et al., 2007). Another element of a corpus, as Biber et al. (1998) call attention to, is that it is a principled accumulation of text available for qualitative and quantitative analysis.

\section{General Service List (GSL)}

West (1953) distributed a list of around 2000 essential vocabulary words known as the General Service List (GSL). GSL gives around 84\% scope of general English in light of over twenty years of computer based corpus studies and a corpus size of 2.5 million to 5 million words.

\section{Academic Word List (AWL)}

As indicated by Coxhead $(2000,2011)$, the AWL words represent $10 \%$ of the tokens in any academic texts ('representative texts from the academic domain', (Coxhead, 2000: 219). It ought to be noticed that West's GSL (1953) filled in as the non-scholarly gauge for the production of the AWL (Brezina and Gablasova, 2015) and Coxhead (2000) excluded the 2000 GSL words from the Academic Corpus.

\section{Nursing Education Word List (NEWL)}

According to Mukundan and Ng (2012), the Nursing Education Word List (NEWL) is a word list of 969 nursing education specialized words selected from a corpus of 3,490,417 words is developed to enhance English for Nursing Purposes (ENP) learning. With 969 technical words in the NEWL, the word list provides coverage of $9.5 \%$ in the selected textbooks.

\section{2,000 most frequent nursing words}

According to Nor Mohamad and $\mathrm{Ng}$ (2013), the 2,000 most frequent nursing words are identified after removing all the functional words in the English language such as articles, pronouns and other functional grammatical items in the language. The GSL word families were not removed at this stage because this 2000 words list is considered as a list to enhance the teaching and learning process. GSL words which are maintained in these 2,000 most frequent nursing words are the words which are considered as the words which are useful and needed for the field of ENP. Moreover, there are 2,157 types in these most frequent nursing words which eventually make it a higher coverage list compared to both GSL and AWL merged. They further state that by recognising the frequently used nursing vocabularies would help students to read better they use the word list. Therefore, it depicts that a specialised corpus should always be established in order to distinguish and identify the important words in the field that provide higher significance to content-specific word list development (Martinez, 2009; Mudraya 2006; Ward, 1999). The words found are remained in their lexicogrammar forms to promote better comprehension of words in 'authentic' or 'real' forms in terms of frequency (see Ward, 2009). 


\section{Methodology}

This present research attempts to investigate the vocabulary coverage as compared to four wordlists in the same level English for Nurses course books written by different authors. The research compares the ENP course books from two different authors where one is from a local author and the other one from an international author. This study takes the form of quantitative research. The computer may achieve a quantitative analysis of word count, for example, or a more nuanced "analysis" of textual patterns (Evans, 1996) and this study utilizes the content two ENP course books used in Intensive English programme for Diploma of Nursing students. The researcher has selected these most popular ENP course books available in Malaysia and which are commonly used in most of the nursing colleges, namely, "Oxford English for Careers Nursing 1" (OEFCN1) written by Tony Grice and "Nursing Your English Second Edition" (NYE) by Siti Salina Salim and Mazura Mastura Muhammad.

WordSmith 4.0 (Scott, 2004) was used in scrutinizing the vocabulary data. It has been verified by numerous studies on various corpuses which have used these tools to analyze texts (Bondi, 2001, Scott, 2001, Henry and Roseberry, 2001, Nelson, 2000, Flowerdew, 2001, Mukundan, 2004). To use this tool, all the associated pages of the ENP books need first be converted into digital documents. After that, scanner with the optical character recognition (OCR) is used to scan these pages they are converted into text files format (.txt). For this step, Abby Fine Reader 8.0 software was used to conserve the authenticity of the texts. The scanning and digitizing procedure has been done in numerous research cases by Mukundan (2007), Mukundan \& Hussin (2007) and Mukundan \& Menon (2007).Then the text files were loaded into WordSmith 4.0 for further scrutiny.

Then, a further analysis was conducted to distinguish the General Service List (GSL) words, the Academic Word List (AWL) words, Nursing Education Word List (NEWL), technical and the 2,000 most frequent nursing words in the books. As for this study, the Nursing Education Word List is considered as ENP technical content words. This is because the number of times these words occurring in ENP texts is moderately low but not in nursing academic texts which are understood to have more of the low-frequency and technical vocabulary. Even though this research looks at only 2 ENP course books, they are actually general course books for ENP students, particularly in the researchers' former institution.

Words that occur in the list of the General Service List words, the Academic Word List Words, the Nursing Education Word List and the 2,000 most frequent nursing words in the books will be isolated and the proportion of the coverage will be described in the following section. Content analysis can be employed utilizing the WordSmith Tools 4.0 software programme as this is a corpus-based research on course books. All the research questions were answered according to the data analysis methods mentioned above in the effort of analyzing the vocabulary coverage according to respective wordlists presented in the prescribed English for Nursing Purposes (ENP) course books.

\section{Results and Discussion}

The statistical data of table 1 shows the differences between OEFCN1 and NYE in certain factors. Firstly, the number of pages and number of token in OEFCN1 is lesser than in number of pages and tokens in NYE. Nevertheless, OEFCN1 has more number of lesson units with smaller number of average number of pages per unit compared to NYE which has less number of lesson units and more average number of pages per unit. The distribution of similar types of words in lengthy number of pages causes the low density ratio for both books. The consistency ratio of the both book read at almost 10 and 9 respectively, indicating that after every 10 and 9 words; a new word is introduced in each course book.

Table 1. Summary of Statistics of OEFCN1 and NYE

\begin{tabular}{lcc}
\hline Course Books & $\begin{array}{c}\text { Oxford English for } \\
\text { Careers Nursing }\end{array}$ & $\begin{array}{c}\text { Nursing Your } \\
\text { English }\end{array}$ \\
\hline No. of Pages & 128 & 357 \\
No. of Units & 19 & 14 \\
Average No. of Pages per Unit & 7 & 27 \\
Tokens & 46682 & 51002 \\
Types & 4739 & 6026 \\
Density Ratio & 0.10 & 0.12 \\
Consistency Ratio & 9.9 & 8.5 \\
\hline
\end{tabular}

Table 2. Words from the Books Found in the GSL

\begin{tabular}{lcc}
\hline Course Books & $\begin{array}{c}\text { Tokens Found in } \\
\text { the GSL }\end{array}$ & $\begin{array}{c}\text { Percentage of Texts } \\
\text { Coverage in the Book } \\
(\%)\end{array}$ \\
\hline Oxford English for Careers Nursing 1 & $39544 / 46682$ & $85 \%$ \\
Nursing Your English & $40928 / 51988$ & $79 \%$ \\
\hline
\end{tabular}


From Table 2, it is clear that OEFCN1 manage to cater $85 \%$ of the words in GSL in the list. A total of 39544 belong to GSL out of 46497 tokens. This shows that the course book is adequate as a GSL is able to cover about $84 \%$ of any tex ts or passages. As for NYE, only $79 \%$ of the running words belong to the GSL. A total of 40928 out of 51988 tokens are identified belong to this list. This figure is lower compared to OEFCN1 and lower compared to the standard percentage of GSL words that should occur in any general English text which is $84 \%$.

Table 3. Words from the Books Found in the AWL

\begin{tabular}{lcc}
\hline Course Books & $\begin{array}{c}\text { Tokens Found in } \\
\text { the AWL }\end{array}$ & $\begin{array}{c}\text { Percentage of Texts } \\
\text { Coverage in the Book } \\
(\%)\end{array}$ \\
\hline Oxford English for Careers Nursing 1 & $1710 / 46682$ & $4 \%$ \\
Nursing Your English & $2600 / 51988$ & $5 \%$ \\
\hline
\end{tabular}

Table 3 shows the coverage of AWL, in OEFCN1 only 4\% of the words are listed in AWL. A total of 1710 out of 46697 tokens are identified as words from AWL. On the other hand, in NYE the percentage of AWL words in the text is higher by $1 \%$ as compared to OEFCN1 which makes it to $5 \%$. Both books have lower coverage than the standard percentage of AWL words in any text which is about $10 \%$.

Table 4. Words from the Books Found in the NEWL

\begin{tabular}{lcc}
\hline Course Books & $\begin{array}{c}\text { Tokens Found in } \\
\text { the NEWL }\end{array}$ & $\begin{array}{c}\text { Percentage of Texts } \\
\text { Coverage in the Book } \\
(\boldsymbol{\%})\end{array}$ \\
\hline Oxford English for Careers Nursing 1 & $1833 / 46682$ & $4 \%$ \\
Nursing Your English & $3629 / 51988$ & $6 \%$ \\
\hline
\end{tabular}

From Table 4, as for the coverage of words in NEWL, only $4 \%$ of the words appeared in the list. A total of 1833 out of 46697 tokens are listed as the words appeared in NEWL. This is considered as a good coverage as the standard percentage of specific word list should cover at least 5\% in a text. However, it does not cover all the technical words in nursing academic texts as claimed by Mukundan and $\mathrm{Ng}$ (2012). According to them, the word list provides coverage of $9.5 \%$ in the selected nursing textbooks. Based on the figure above, NYE showed a higher coverage of words in NEWL which is $6 \%$. This is slightly higher than OEFCN1 and also slightly higher than the standard coverage which is $5 \%$. A total of 3629 out of 51988 tokens are indentified which belong to NEWL.

Table 5. Words from the Books Found in the 2000 most frequent nursing words wordlist

\begin{tabular}{lcc}
\hline Course Books & $\begin{array}{c}\text { Tokens found in the } \\
\text { 2000 most frequent } \\
\text { nursing words wordlist }\end{array}$ & $\begin{array}{c}\text { Percentage of Texts } \\
\text { Coverage in the Book } \\
(\%)\end{array}$ \\
\hline Oxford English for Careers Nursing 1 & $29877 / 46682$ & $64 \%$ \\
Nursing Your English & $38471 / 51988$ & $74 \%$ \\
\hline
\end{tabular}

From Table 5, we see that OEFCN1 managed to cover about $64 \%$ of the total tokens appear in 2000 most frequent nursing words wordlist. On the other hand, NYE make up to $74 \%$ of the the total tokens which appear in 2000 most frequent nursing words wordlist. As the wordlist is created in the attempt to have a combined wordlist to assist student nurses, it is proven that the 2000 most frequent nursing words wordlist is not able to cover as much tokens as compared to GSL, AWL and NEWL combined. This is possible due to the fact the 2000 most frequent nursing words wordlist does not contain all the words which appear in GSL and AWL.

\section{Conclusion}

English for Nursing Purposes (ENP) course plays a vital role especially in Malaysia where most of the student nurses are non-native speakers of the language. Trying to figure out the right vocabulary to be taught and learnt can be difficult 
and time consuming as there is no inclusive word list, especially one that is academic based. From this study, it is learned that teachers and students should be exposed to the available wordlists such as GSL, AWL, NEWL and the 2000 most frequent nursing words to have a better understanding on the nature of words that occur in ENP. This will help primarily the students to be able to comprehend nursing texts better and in fact to enhance their abilities in using the language in terms of written and spoken at the workplace. Course books play an essential role in assisting students especially at tertiary level. Course book evaluation should be integrated as part of the curriculum development in any teaching institution. Corpus-based evaluation must be carried out from time to time during a semester in order to improve and ensure the effectiveness of the course books. Through corpus based evaluation, publishers and authors can prevent designing course books in an ad hoc manner based on instinct, thus avoiding unnecessary vocabulary to be inserted in the course books which may not be useful and also time consuming to learn. Ultimately, corpus based evaluation will ensure both the teachers and student nurses to be aware of the available wordlists and specialized vocabulary in the course and this will lead to a more meaningful teaching and learning of ENP.

\section{References}

Biber, D., S. Conrad \& R. Reppen (1998). Corpus Linguistics: Investigating Language Structure and Use. Cambridge: Cambridge University Press.

Bondi, M. 2001. “Corpora and language variation: Reflexivity across genres”. In M. Ghadessy, A. Henry and R.L. Roseberry (eds.). Small corpus studies and ELT: theory and practice. Amsterdam: John Benjamins Publishing Co. 135174.

Coxhead, A. (2000). A New Academic Word List. TESOL Quarterly, 34(2):213-238.

Dudley-Evans, Tony (1998). Developments in English for Specific Purposes: A multi-disciplinary approach. Cambridge University Press. (Forthcoming)

Evans, W. (1996). Computer-Supported Content Analysis: Trends, Tools, and Techniques. Social Science Computer Review, 14(3), 269-279.

Ewer, J. R. - Latorre, G. (1969), A Course in Basic Scientific English, Londres, Longman.

Flowerdew,J.(2001).Using small corpora to investigate learner needs: Two vocabulary research tools. In M. Ghadessy, A. Henry \& R. L. Roseberry (Eds.), Small corpus studies and ELT: Theory and practice.(pp.68-92).Amsterdam:John Benjamin

Hutchinson, Tom \& Waters, Alan (1987). English for Specific Purposes: A learner-centered approach. Cambridge University Press.

Martinez, I.A., Beck S.C. \& Panza, C.B. (2009). Academic vocabulary in agriculture research articles: A corpus-based study. English for Specific Purposes, 28,183-198. Doi:10.1016/j.esp.2009.04.003

McEnery, T. \& Gabrielatos, C. (2006). English corpus linguistics. In Aarts, B. \& McMahon, A. (Eds.), The Handbook of English Linguistics (pp. 33-71). Oxford: Blackwell.

Mudraya, O. (2006). Engineering English: a lexical frequency instructional model. English for Specific Purposes,25,235-256. Doi:10.1016/j.esp.2005.05.002

Mukundan, J. (2007). Irregularities in Vocabulary Load and Distribution in Same Level Textbooks Written By Different Writers. Indonesian JELT 3/1, 99- 118.

Mukundan, J.\& Menon, S. (2007). The Language of Mathematics, Science and English Language Textbooks: A Comparative Corpus Based Study. ELT Matters 4 (pp 244-271). Serdang: Universiti Putra Malaysia Press.

Mukundan, J. and Hussin, A (2007).A Forensic Study of Vocabulary Load and Distribution in Five MalaysianSecondary School English Textbooks (Forms 1-5). Pertanika J.Soc.Sci. \& Hum. 15(2): 59-74

Mukundan, J. (2009). ESL Textbook Evaluation: A Composite Framework. LAP Lambert Academic Publishing.Mukundan, J. \& Menon, S. (2007). The Language of Mathematics, Science and English Language Textbooks: A Comparative Corpus Based Study. In ELT Matters 4 Developments in English Language Learning and Teaching ,ed.Mukundan, J. \& Menon, S., pp. 244-271. Serdang: Universiti Putra Malaysia Press.

Mukundan, J., \& Ng, Y. J. (2012). Development of a Technical Nursing Education Word List (NEWL). International Journal of Innovation in English Language Teaching and Research, 1(2), 105-124.

Nation, P. \& Waring, R. (1997). Vocabulary size, text coverage and word lists. In N.Schmitt \& M.McCarthy (Eds.). Vocabulary: Description, Acquisition and Pedagogy (pp. 6-19). Cambridge: Cambridge University Press.

Nation, P (2001). Learning Vocabulary in Another Language. Cambridge: Cambridge University Press.

Nelson, M. 2000. A corpus-based study of the lexis of business English and business English teaching materials. Unpublished dissertation. Manchester: University of Manchester.

Nor Mohamad, A.F., \& Ng, Y. J. (2013). Corpus-based Studies on Nursing Textbooks. Advances in Language and Literary Studies, 4(2), 21-28.

Schmitt, N. (2000).Vocabulary in Language Teaching. Cambridge: Cambridge University Press. 
Scott, M. (2004). Version 4.0 WordSmith Tools. Oxford: Oxford University Press.

Scott, M. 2001. "Comparing corpora and identifying key words, collocations, frequency distributions through the WordSmith Tools suite of computer programs". In M. Ghadessy, A. Henry and R.L. Roseberry (eds.). Small corpus studies and ELT: theory and practice. Amsterdam: John Benjamins Publishing Co. 47-70

Selinker, L., Todd Trimble, M. \& Trimble, L. (1976). Presuppositional rhetorical information in EST discourse.

Swales, J. (1971), Writing Scientific English, London, Nelson.

Vaclav Brezina, Dana Gablasova; Is There a Core General Vocabulary? Introducing the New General Service List. Appl Linguist 2015; 36 (1): 1-22. doi: 10.1093/applin/amt018

Ward, J (1999). How a Large Vocabulary do EAP engineering students need? Reading in a Foreign Language, 12(2),309-323

Ward, J. (2009). A basic engineering English word list for less proficient foundation engineering undergraduates.English for Specific Purpose, 28, 170-182.

West, M. (1953). A general service list of English words. London: Longman, Green \& Co. 